\begin{tabular}{c} 
Volume and Issues Obtainable at Center for Sustainability Research and Consultancy \\
Journal of Business and Social Review in Emerging Economies \\
ISSN: 2519-089X (E): 2519-0326 \\
Volume 6: No. 2,June 2020 \\
JSRᄃ \\
Journal homepage: www.publishing.globalcsrc.org/jbsee \\
\hline
\end{tabular}

\title{
Unconditional Cash Transfers and Women Empowerment: The Case of Benazir Income Support Programme (BISP) in Pakistan
}

\author{
${ }^{1}$ Tehmeena Iqbal, ${ }^{2}$ Ihtsham Ul Haq Padda, ${ }^{3}$ Shujaat Farooq \\ ${ }^{1}$ Ph.D Scholar, Federal Urdu University of Arts, Science\& Technology, Islamabad, Pakistan. \\ tehmypominfal@live.com \\ ${ }^{2}$ Assistant Professor, Federal Urdu University of Arts, Science \& Technology, Islamabad, Pakistan. \\ ihtsham91@yahoo.com \\ ${ }^{3}$ Additional Director General (Monitoring \& Evaluation), Benazir Income Support Programme (BISP), \\ Islamabad, Pakistan. shujaatfarooq@gmail.com
}

\begin{tabular}{|c|c|}
\hline A I & \multirow{5}{*}{$\begin{array}{l}\text { This study has explored the welfare impact of Benazir Income } \\
\text { Support Program's (BISP) unconditional cash transfers on women } \\
\text { empowerment. The program was initiated in } 2011 \text { by the } \\
\text { government of Pakistan. The impact has been computed by using } \\
\text { two follow up rounds i.e, } 2011 \text { \& } 2016 \text { where baseline was carried } \\
\text { out in } 2011 \text { and follow-up round was carried out in } 2016 \text {. } \\
\text { Regression Discontinuity Design approach was used to measure } \\
\text { casual effects of the BISP cash transfers on women empowerment } \\
\text { by selecting target and control groups based on proxy means test. } \\
\text { The overtime impact have been estimated by employing Difference } \\
\text { in Difference (DiD) model on panel households from } 2011-2016 \text {. } \\
\text { The study observed that BISP led to improve socio-economic } \\
\text { wellbeing of the beneficiary women. It has brought improvement in } \\
\text { women mobility and women participation in voting. The important } \\
\text { contribution is an improvement in the aspect of socio-economic and } \\
\text { political empowerment and women mobility across time and } \\
\text { overtime. This showed continues support for longer period brought } \\
\text { desired results. }\end{array}$} \\
\hline Host & \\
\hline & \\
\hline $\begin{array}{l}\text { isfer; } \\
\text { Socio- }\end{array}$ & \\
\hline & \\
\hline EN & \\
\hline
\end{tabular}

Corresponding author's email address: tehmypominfal@live.com

Recommended citation: Iqbal, T., Haq Padda, I.U.H., \& Farooq, S. (2020). Unconditional Cash Transfers and Women Empowerment: The Case of Benazir Income Support Programme (BISP) in Pakistan. Journal of Business and Social Review in Emerging Economies, 6(2), 401-418

DOI: $10.26710 /$ jbsee.v6i2.1098

\section{Introduction}

The role of women in nation building cannot be underestimated. An empowered woman can contribute in society in many ways. Women's greater evenhandedness in her own decision making is considered as desirable (United Nations, 1995). Thus, the concept of women empowerment contains their decision making choices and context in which these decisions can be exercised. The instrumental values of women empowerment include their decision making in all other spheres especially in child welfare (Hoddinott \& 
Haddad, 1995; Thomas, 1990, 1997; Kabeer, 2011).

The social security interventions aim to safeguard vulnerable segments of society through various channels in order to counterbalance the substantial decline in income from work that results from sickness, natural disasters/threats, unemployment, invalidity, death of main earners, old age and employment injury etc. (Shepherd et al., 2004; World Bank, 2018). Safety nets used as a pragmatic mechanism to reduce poverty, to improve socio-economic wellbeing, to protect poor from uncertain risks and shocks and to enhance livelihood of the destitute. The last decade has witnessed an inspiring growth in various kinds of cash transfers programmes in terms of numbers and volume in the developing world. A rigorous analysis from various studies shows that cash transfers have had positive and significant impact on consumption, educational attainment, health, poverty, socio-economic wellbeing and women empowerment (Baired et al. , 2013; De Braeuw , 2014; Haushofer \& Shapiro, 2016; Ambler, 2016).

The role of social schemes is very important in enhancing women empowerment as these schemes often designed to target female-headed households and transfer cash to women. The potential of prevailing social schemes is highly considerable in improving women empowerment in asset accumulation, participation status, negotiation and control over those institutions that may affect their lives (FAO, 2015). A set of social protection policies and programmes that target only women to improve their skills may increase access to resources, heighten their participation in labor market and increase women mobility which not only lead to improve their economic empowerment but also effectively reduce poverty and vulnerabilities among poor segments (Holmes \&Jones, 2013; Sabates-Wheeler \& Devereux, 2007).

Literature about safety nets impact on women empowerment shows mixed evidence of impact on variety of indicators pertinent to women empowerment. Some studies show little evidence of impact on women empowerment (Attanasio \& Lechene, 2002; Handa et al., 2009), whereas some observed positive impact (Adato et al., 2000; Haushofer \& Shapiro, 2016). Many studies conducted by researchers to dig out its impact on variety of indicators but within limited scope by using either cross-sectional data or primary data of one or few districts. The study of Shahzad (2011) has computed impact of BISP cash assistance on women empowerment by using primary data in selected villages of Punjab and Sindh whereas, the study of Nayab \& Farooq (2014) estimated BISP impact on welfare indicators by using HIES data for 2010, OPM measured impact on various indicators such as livelihood strategies, poverty, asset accumulations, women empowerment, poverty, child schooling and child nutrition three consecutive rounds 2013, 2014 and 2016 by using cross sectional analysis Regression Discontinuity Design (RDD) model. Ambler \& De Brauw (2017) computed impact of BISP on selected indicators of women empowerment by using 2013 rounds data and by employing RDD model.

BISP is a flagship programme of Government of Pakistan that was emerged in 2008 to protect the poor from high food inflation and to increase the declining purchasing power of the defenseless. The long term objective of the BISP is to meet SDGs to eradicate poverty and empower women (GoP, 2018). Currently the programme offers cash assistance to 5.8 million ever-married women with a quarterly stipend of PKR 5500 (around US\$ 35). Besides, under conditional cash transfers, the programme aims to assist the children of poor families to complete their primary level education, around 3.4 million children are enrolled and their mothers were given additional top-up of PKR 750 per quarter with the condition that child will attend school and meet minimum attendance of 70 percent (GoP, 2018).

The present study is carried out to check whether the BISP's UCT payments have a positive impact on women empowerment or not? The analysis is carried out by using set of various indicators pertinent to gender norms from men and women perspectives, women autonomy/mobility and women socio-economic and political empowerment. Since programm's inception, the beneficiaries and non-beneficiaries have been targeted through Proxy Means Test (PMT) that is poverty score determined the eligibility criteria for the programme where the households having poverty less than or equal to 16.17 is served as target group/beneficiary households whilst the households having poverty score 16.18 to 21.17 is declared as non-beneficiary households. 
This study is a contribution to existing literature in many ways as in South Asian countries, specifically in Pakistan where women mobility/ autonomy and decision making power are very much low (Jeejebhoy \& Sathar, 2001). Second, the BISP cash transfer programme is specifically designed to empower poor ever married women of Pakistan since 2011 to meet SDGs. Third, the programme is largest and unconditional in nature similar to other programmes implemented in Sub-saharan Africa, (Bonilla et al; 2016) that expand quickly over time. Fourth, the study has used robust impact evaluation techniques to estimate the impact as previous studies were qualitative in nature and lacks robust impact evaluation technique specifically longitudinal survey. The rest of the study is structured as follows. Section 2 summarizes international and national viewpoint of various studies related to impacts of safety nets on women empowerment. Section 3 explains data description, methodology employed while Section 4 encompasses empirical findings of the study.

\section{Literature Review}

The SSNs are broadly perceived as protective mechanism to help destitute and underprivileged and to augment inclusive growth (Barrientos \& Hulme, 2008). Besides, safety nets used as pragmatic mechanism that served as ladder for the poor to graduate them out of poverty trap and protect from socio-economic instabilities. Various studies are carried out to dig out welfare impact of safety nets, however, this study is exclusively carried out to dig out the welfare impact of BISP programme on women empowerment by using BISP Impact Evaluation Survey dataset from 2011-2019 rounds. This section contains national and international studies assessment pertinent to safety nets impact on welfare indicators of women empowerment.

\subsection{Does Cash Assistance Empower Women? Review Perspective}

The notion to empower women through providing unconditional cash transfers to women is the key objective of the BISP cash assistance programme. The idea to empower women was first derived through original plan of Progresa/Oportunidades that was designed to empower women through increasing her income that ultimately improve her agency within households (Schultz, 2004, Ambler \& De Brauw, 2017). The evidences of international and national studies are mixed pertinent to assessment of safety nets on women welfare, empowerment and decision making (De la O Campos, 2015). By looking into relative effectiveness of the cash transfer Yoong, Rabinovich and Diepenveen (2012) suggests that bargaining power of the women within households depends on social prevailing norms, share of income and her formal legal rights. Hence lack of all these can reduce impact of safety nets on improving her bargaining power ability within households. Handa (2009) explained that cash transfer grant can crowd out any kind of intra-households transfer from men to women instead of improving women bargaining power ability within households. The argument of Handa, (2009) is consistent with the substantiation of Progresa impact evaluation that conferred that cash transfers led to improve women control over cash assistance but little else within households (Attanasio \& Lechene, 2002). The arguments of Adato et al, (2000) on Progresa Programme is contrary to Attanasio \& Lechene, (2002) and Handa (2009) that depict positive impact of the programme on self-esteem and self-confidence on women. Jejeebhoy \& Sathar, (2001) in their study demonstrated that women residing in Punjab province of Pakistan are not permitted to move freely than those residing in Uttar Pardesh in India whereas Lodhi (1996) explored that women have no rights to move freely outside of their habitants.

Evaluation of safety nets in other countries also found positive and significant impact of safety nets on women empowerment such as De Brauw et al. (2014) found positive and significant impact of Bosla Familia programme in Brazil whereas, Ambler (2016) found that old age pensions programmes in South Africa and extended allowances rights programme in Brazil produce favorable impacts on the education level and health status of the children of beneficiary women (Duflo, 2003; Rangel, 2006). Natali et al; (2016) estimated the impact of Zambia's unconditional cash transfer Child Grant programme (CGP) that targeted to poor women having young children on savings and women's participation in non-farm enterprises. The results indicate that the CGP led to improve savings of the beneficiary women who hold less decision making power at the baseline. Handa et al (2015) also inferred the impact of CGP on 
maternal health in Zambia by employing randomized design approach and DiD multivariate regression. The result indicates that the women beneficiaries of the programme have access to better maternal health facilities.

In addition, several evidences showed that programmes specifically targeted to women improve women and their children's clothing (Lundberg et al., 1997). The saving products initiated for women in Philippines improved women decision making powers (Kaarlan et al., 2007). The micro credit programmes proliferates the financial resources power and mobility to various places of female beneficiaries in Bangladesh are observed by Pitt et al. (2006). The programme pertinent to education designed at community levels exerted positive impact on empowerment outcomes and employment status of beneficiary women (Kandpal, 2013) whilst interventions combined with provision of vocational training and awareness about health and risky behaviors reduces sexual activities, pregnancy among females aged 14-20 and improved income generating activities in Ugenda (Bandiera, 2012) . The Girl Power cash transfer programme in Malawi shows positive and significant role in improving school attendance, increase access to financial resources, decline in teen age pregnancies, improvement in health facilities and decrease in early age marriages (Baird et al, 2013). Shahzad (2011) assessed the impact of BISP cash assistance programme on women empowerment by using primary data and found that large number of beneficiary women residing in interior part of Sindh and Southern Punjab benefiting from the programme. Oxford Policy Management (OPM) (2016) assessed impact of BISP programme on variety of indicators including women empowerment indicators by employing Fuzzy Regression Discontinuity Design Approach (FRDD) on 2016 data set. The study indicated positive and significant impact of the programme on women access to cash in emergency, women mobility to various places and child nutrition of girls. Ambler \& De Brauw, (2017) observed positive and significant impact of BISP cash assistance programme of some indicators of women empowerment by using FRDD approach for data set of 2011 and 2013. Zuneira (2018) assessed Zakat and BISP impact on women welfare by using HIES data set and employing Propensity Score Matching. The study found positive impact of the Zakat programme on women welfare whilst observed marginal impact of the BISP programme on women welfare.

\subsection{BISP Background and Performance}

The implementation of Benazir Income Support Programme (BISP) in 2008 laid the formal foundation of social protection in Pakistan with twin goals to eradicate extreme poverty and to empower poor women. The BISP cash transfer programmes were effectively targeted poorest through nationwide targeting mechanism based on Proxy Means Test (PMT). This mechanism to target beneficiary through PMT was developed in 2010 that replaced with criteria of selection of beneficiaries through local parliamentarian to selection of beneficiaries through poverty score. The PMT comprises of the poverty score card information developed initially from Pakistan Living Standards Measurement (PSLM) Survey 2007-08. Afterward, government of Pakistan conducted a poverty score card survey in 2010-11 covered 27 million people ( $87 \%$ coverage of total population) by devising 23 variables in order to calculate poverty score for each surveyed household. For selection of desired group of beneficiaries for the programme, the eligibility criteria were devised wherein, eligibility threshold of 16.17 were established to provide cash grant to households having poverty score 16.17 or less. There could be multiple eligible families within the eligible household. Crucially, within each eligible family a receiver woman was identified, defined as every ever-married woman having a valid Computerized National Identity Card (CNIC) who is then eligible to receive the cash benefit. The households having score just above 16.17 or less than 21.17 declared as control group.

The beneficiaries of BISP were envisaged to provide cash grant on quarterly basis to the eligible women. The grant has been gradually increased from PKR 3000/ per family in FY 2008-09 to PKR 3600 during FY 2013-14 followed by PKR 4500 in FY 2014-15, PKR 4700 in FY 2015-16 and PKR 5000 in July, 2019. Despite of change in political regimes, programme expanded overtime with its budgetary allocation of PKR 34 billion in 2008 to PKR 180 billion in June, 2019. Currently BISP is making payments to 5.8 million beneficiaries throughout country, 98.5 percent of them are receiving payment through technology- 
based payment mechanisms i.e. BISP Debit Card (BDC) and Biometric Verification System (BVS). Besides UCT, under conditional cash transfers (CCT) so far BISP has enrolled 3.4 million children (aged 4-12 years) for provision of primary education under Waseela-e-Taleem (WeT) programme.

\section{Data and Methodology}

\subsection{Data Description}

This study has used two rounds of BISP impact evaluation survey to measure impact of cash transfers on women empowerment. The baseline is carried out in 2011 and follow up round was carried out in 2016. Two combinations of dataset have been used for the analysis one is panel household dataset collected for evaluation of BISP through 2011-2016 and other is cross-sectional household's data set for 2016 round.

Table 1: Province wise Surveyed Households through 2011-2016

\begin{tabular}{|c|c|c|c|}
\hline Province & Baseline Survey & 2016 Round & $\begin{array}{c}\text { Panel households } \\
\text { 2011-2016 } \\
\end{array}$ \\
\hline Punjab & 3,162 & 3,286 & 932 \\
\hline Sindh & 2,334 & 3,007 & 1199 \\
\hline KP & 2,054 & 2,175 & 876 \\
\hline Balochistan & 1,125 & 671 & 226 \\
\hline Total & 8,675 & 9,139 & 3233 \\
\hline
\end{tabular}

Source: Estimated from the BISP Impact Evaluation Survey 2011- 2016 by authors

\subsubsection{Baseline Round 2011}

The baseline round was conducted in 2011 by Oxford Policy Management (OPM) for Impact Evaluation Survey of BISP cash transfer. The dataset covers all four provinces of Pakistan and the chosen sample households were representative households nearest to the eligibility threshold 16.17. The sample frame was constructed as follows: The primary sampling units (PSUs) were randomly selected from the sampling frame of PSLM 2007-08 survey stratified at the regional and provincial level. It was prerequisite to generate sample that fulfills RDD approach criteria for analysis. However, the poverty score card survey was not conducted at the time of baseline survey carried out. For reconstruction of PMT required for targeting BISP beneficiaries, listing exercises at households level were made in selected PSUs which were encompassing list of variables required for PMT reconstruction. From listed households, a pre-determined number of households chosen and PMT was calculated for these selected households. On average 100 households PMTs were computed in each PSU. Afterward, the households were divided into two groups based on predicted poverty score. The households having poverty score equal to 16.17 or less declared as eligible. Whilst the households having poverty score just above than 16.17 but less than 21.17 declared as non-eligible households. Respective sample from each beneficiary and non-beneficiary households were then randomly selected. The baseline survey carried out from 488 PSUs with average sample per PSU of 19 households in rural cluster and 15 households in urban cluster covered 8,675 households nationwide.

\subsubsection{Follow-Up Round 2016}

The second follow-up round covers 9,139 UCT households nationwide. In RD estimation, it is best to conduct analysis on observations closest to the eligibility threshold. In baseline survey, the PMT was reconstructed, the resulting poverty score for large number of observations lies far from the eligibility threshold and based on reconstructed PMT that . In 2016 round, for increasing number of observations around the eligibility cut-off point, the sample was increased. The 2016 round includes only those households that were matched in baseline and with 2013 along with refreshing sample by adding new households to increase the number of households around the poverty score eligibility cut-off. As one can expect high attrition from 2011 to 2016 due to matching issues as baseline was carried out just right before poverty score card survey. Therefore, the baseline households matched with the poverty score card with 2016 round were considered as panel households through 2011-2016 and rest households have been dropped. The panel data have only 3233 panel households where 2299 are beneficiary households and 934 are non-beneficiary households from 2011-2016. 


\subsection{Methodology}

To investigate the impact of the BISP unconditional cash assistance on selected indicators pertinent to women empowerment, we have employed three stage analysis such as descriptive (bi-variate) as well as multi-variate analysis method. In first stage analysis, we have computed summary statistics of sociodemographic and economic characteristics of the households by segregating beneficiary and nonbeneficiary households based on poverty score lies within $+/-5$ bandwidth in each round. The performances of indicators pertinent to women empowerment have also been assessed by using two bandwidth from the eligibility threshold in each round. In multi-variate analysis, we have employed RDD approach to infer the impact of the BISP cash programme on selected indicators whereas DiD model used to guage the overtime impact of the programme on women empowerment.

\subsection{Regression Discontinuity Design (RDD) Approach}

The key design of BISP allows us to employ RDD for measuring causal impact of the programme. Households having PMT 16.17 or less is served as target group or beneficiary group whereas households having PMT just above 16.17 is declared as control group or non-beneficiary households. One of the assumption of RDD demonstrate that eligible and non-eligible households nearest to the eligibility threshold should only be differ due to BISP designed eligibility criteria. Any other change that occurred above and below poverty cut-off should not be changed discontinuously around the eligibility threshold. The primary threat to the programme would be observable if some other cash transfer may use the same criteria for selection of beneficiaries. But in this case, no other programme is under implementation that uses these criteria for selection of beneficiaries.

The RDD approach allows estimating impact of the programme for households located nearest to the eligibility threshold. In our case, we are unable to dig out the impact of the programme on all other beneficiary households as all eligible households are not BISP beneficiaries and some of nonbeneficiaries lying above the eligibility threshold are BISP beneficiaries. We have employed here, Fuzzy RDD to infer the impact as this RDD does not need perfect compliance. The use of bandwidth in RD estimation is very much important as the observations located far from the eligibility threshold having weak internal validity, less similar with each other which may induce bias whist observations lies nearest the eligibility threshold may be smaller in number that may induce variance and limited statistical inferences. Here we have used optimal bandwidth for each outcome variable that allows bandwidth to vary above and below the cut-off point. We have also estimated RDD impact on outcome variable by using fixed bandwidth of $+/-5 \&+/-3$ for each round in 2013, 2016 and 2019 in order to see the impact of the programme on outcome variable. Our dataset for 2013 round having panel household whilst 2016 round analysis is based on cross-sectional households.

\subsection{Difference in Difference (DiD) Model}

The study has used the panel household's data set to gauge the impact of the porogramme over time as sufficient time has been passed from 2011 to 2016. Thus one can expect, long run impact of the programme on welfare indicators of women empowerment. The analysis is carried on 3364 panel households on indicators of gender norms from women and men's perspective, women mobility to various places and women socio-economic and political empowerment. The DiD model is best to employee here as the quasi experimental design (QED) requires that the beneficiary and non-beneficiary households comparable if they exhibits on average similar characteristics and follow parallel trend assumption. In our case, we have constructed panel of those beneficiary and non-beneficiary households having on average similar socio-economic and demographic characteristics and rest were dropped (See Table 2). Second, the approach combines with intervention and without intervention approach along with before and after approach by using baseline (pre-intervention) and follow-up (post intervention) data (Khandker et al., 2009). The DiD model used to assessed the impact of the programme on the outcome variable ' $\mathrm{Y}$ '. Employing simple DiD model is misrepresentative as it does not include time invariant characteristics and considered all households in beneficiary and non-beneficiary groups are similar and errors of households are more likely to be correlated in pre-treatment and post- treatment. DiD model with 
fixed effects is more robust and rigorous to use as it clusters errors at household's level and avoid serial correlation. The following model have been used for employing DiD with fixed effects:

$$
\text { Outcome }=\beta 0+\beta 1 \text { time }+\beta 2 \text { bisp_treat }+\beta 3(\text { time } * \text { bisp_treat })+F E+\varepsilon
$$

Where the outcome variables are gender norms, women mobility to various places and socio-economic and political empowerment respectively. is CPI, MPI, Headcount poverty and Per adult equivalent monthly consumption expenditures respectively, $\beta 0$ is the constant term, bisp_treat is a dummy variable, ' 0 ' is the indicator for the non-beneficiary group and ' 1 ' indicates the beneficiary group. Time is also a dummy variable with 0 if the time is 2011 and 1 if the time is 2016; time*bisp_treat is the interaction term, the product of time and bisp_treat; FE is each household's fixed effect and $\varepsilon$ is error term. Here $\beta 3$ is the coefficient of the DiD. The negative value of $\beta 3$ depicts the negative impact of the BISP cash assistance on women empowerment indicators whereas positive value of $\beta 3$ indicate the positive impact of BISP cash assistance over time.

\subsection{Measures of Empowerment Indicators}

Women empowerment have measured by devising various dimensions and indicators. The indicators pertinent to dimension of gender norms have been categorized into binary variables. The positive outcome is coded as ' 1 ' whereas negative outcome coded as ' 0 '. To measure the women empowerment from men's perspective, the estimations has also been made from men's perspective. The second dimension encompasses indicators pertinent to women autonomy/mobility to various places such as move alone to visit market, friend's home, health center and religious center. Women index is also generated by summing up all possible positive outcomes. The third dimension contains outcome indicators pertinent to socio-economic and political empowerment. The dimension of socio-economic and political empowerment includes indicators of women voting decision in election, women decision power of her own earned income, decision of having an another child, minor purchases decision, small investment decision, child education decision, participation in groups outside were included in this dimension. The outcome indicators and data source detail is illustrated in Table 1 (Appendix-II)

\section{Results and Discussions}

In this section socio-demographic and economic profiles of the households have been discussed based on poverty score that segregate beneficiary households to non-beneficiary households at eligibility threshold. Furthermore, performances of women empowerment indicators are also computed around the eligibility threshold. Finally the RD and DiD results are discussed on various dimensions of women empowerment in separate sections.

\subsection{Socio-Demographic and Economic Profile of the Households}

The socio-demographic and economic profiles of the households contain information pertinent to household size, number of male and female adults, education of the head, employment status etc. The household size lies between 7 to 8 members in all rounds indicating no significant change. Numbers of female and male adults has increased from 1.9 to 2.2 and 1.8 to 2.1, respectively from 2011 to 2016. The average age has increased from 46 years to 48 for the same period. The female headed households have increased from $6.6 \%$ to $11.1 \%$ overtime. The education of households head has also increased from 2.1 years to 2.4 years. The high dependency ratio shows decreasing trend in 2016. The alarming issue is that employment level of households heads has significantly decreased across time from 81.6 percent to 75.2 percent. This may be due to using same households for all rounds so many heads may have reached at retirement age during this period. The socio-demographic and economic profiles of the households show that all households' lying within $+/-5$ bandwidths of poverty score on average are similar in characteristics and cane be comparable.

Table 2: Socio-Demographic \& Economic Status of Households (Within +/- 5 Bandwidth)

\begin{tabular}{|l|l|l|l|c|}
\hline \multirow{2}{*}{ Characteristics } & \multicolumn{3}{|c|}{ Round 2011 } & \multicolumn{2}{|c|}{ Round 2016 } \\
\cline { 2 - 5 } & $\begin{array}{c}11.17 \text { to } \\
16.18 \text { to }\end{array}$ & $\begin{array}{c}11.17 \text { to } \\
16.17\end{array}$ & 16.18 to 21.17 \\
\hline
\end{tabular}




\begin{tabular}{|l|c|c|c|c|}
\hline Household size (average) & 7.6 & 7.9 & 7.7 & 7.2 \\
\hline No. of male adults in households (15-64) & 1.8 & 1.9 & 2.1 & 2.0 \\
\hline No. of female adults in households (15-64) & 1.9 & 1.9 & 2.2 & 2.1 \\
\hline Age of the head (Average) & 46.3 & 44.9 & 47.9 & 48.3 \\
\hline Female head of the household (\%) & 6.6 & 8.4 & 11.1 & 13.8 \\
\hline Presence of disables (\%) & 32.8 & 31.5 & 22.7 & 22.2 \\
\hline *High dependency ratio (\%) & 56.8 & 48.6 & 37.7 & 34.1 \\
\hline Head education (No of years) & 2.1 & 2.4 & 2.4 & 2.9 \\
\hline Head employed (\%) & 81.6 & 76.4 & 75.2 & 72.1 \\
\hline N & $\mathbf{1 3 5 6}$ & $\mathbf{1 1 3 5}$ & $\mathbf{3 5 3 6}$ & $\mathbf{4 0 0 8}$ \\
\hline
\end{tabular}

*Dependency ratio is number of dependent members (below 15 or above 64) divided by number of independent. Low dependency means if ratio is 0-0.05, medium dependency mean 0.51-1 and high dependency means $>1$ Source: Estimated from the BISP Impact Evaluation Survey 2011 - 2016 by authors

\subsection{Women Empowerment Indicators Performance}

The women empowerment indicators performance in each round has been estimated by taking averages of all outcome variables across all households. Table $3 \& \mathbf{4}$ demonstrate averages of all outcome indicators under each dimension.

Table 3: Women Empowerment Indicators Performance within +/- 5 Bandwidth (Average)

\begin{tabular}{|c|c|c|c|c|}
\hline \multirow[t]{2}{*}{ Welfare Indicators } & \multicolumn{2}{|c|}{ Baseline 2011} & \multicolumn{2}{|c|}{ Round 2016} \\
\hline & 11.17 to 16.17 & $\begin{array}{l}16.18 \text { to } \\
21.17\end{array}$ & $\begin{array}{c}11.17 \text { to } \\
16.17\end{array}$ & 16.18 to 21.17 \\
\hline \multicolumn{5}{|c|}{ Women Participation in Voting } \\
\hline Punjab & 62.0 & 69.6 & 91.4 & 86.7 \\
\hline Sindh & 77.3 & 75.9 & 90.9 & 80.4 \\
\hline KP & 33.7 & 39.6 & 68.9 & 61.6 \\
\hline *Balochistan & 81.5 & 77.7 & 89.4 & 85.7 \\
\hline \multicolumn{5}{|c|}{ Gender Norms (Female Response) } \\
\hline $\begin{array}{l}\text { Disagreed that family decision should be taken by } \\
\text { men }\end{array}$ & 14.7 & 20.0 & 20.4 & 20.1 \\
\hline $\begin{array}{l}\text { Agreed if wife is working outside, husband should } \\
\text { help in chores }\end{array}$ & 73.8 & 74.3 & 72.9 & 73.7 \\
\hline $\begin{array}{l}\text { Agreed if married women allows to works outside } \\
\text { if she likes }\end{array}$ & 74.7 & 76.3 & 76.4 & 77.3 \\
\hline Agreed to express her opinion & 82.5 & 82.9 & 88.1 & 86.9 \\
\hline Disagreed if being beaten by her husband & 17.8 & 19.3 & 10.0 & 10.0 \\
\hline Disagreed to send son to school than daughter & 80.6 & 81.9 & 67.9 & 69.1 \\
\hline \multicolumn{5}{|c|}{ Gender Norms (Male Response) } \\
\hline $\begin{array}{l}\text { Disagreed that family decision should be taken by } \\
\text { men }\end{array}$ & 18.5 & 18.9 & 21.6 & 25.6 \\
\hline $\begin{array}{l}\text { Agreed if wife is working outside, husband should } \\
\text { help in chores }\end{array}$ & 71.5 & 71.9 & 74.3 & 76.2 \\
\hline $\begin{array}{l}\text { Agreed if married women allows to works outside } \\
\text { if she likes }\end{array}$ & 50.5 & 50.4 & 49.1 & 49.8 \\
\hline Agreed to express her opinion & 70.4 & 71.7 & 84.5 & 84.4 \\
\hline Disagreed if being beaten by her husband & 27.4 & 23.4 & 16.1 & 17.1 \\
\hline Disagreed to send son to school than daughter & 70.0 & 72.9 & 73.9 & 77.5 \\
\hline
\end{tabular}

Source: Estimated from the BISP Impact Evaluation Survey 2011 - 2016 by authors. Note: The averages of baseline and 2016 round are based on cross-sectional household's lies within $+/-5$ bandwidth.

The averages of outcome indicators across time show positive or flat trend in many variables except in few indicators of gender norms. The describing opinion that disagree that "wife should tolerate being beaten by her husband" shows increasing trend across time in female response while opposite response have received from male. The averages across time pertinent to gender norms show variation as majority of the men are of the view that women should work outside if she likes and having right to express opinion but on other side many of them did not allow women to involve in minor family decisions. The averages of women mobility shows increasing trend across time demonstrate women mobility improved 
over time in each round. Women mobility to friends' home, visit to market and health center was 56.6, 40.9 and 40 percentage in 2016.

Table 4: Women Empowerment Indicators Performance within +/- 5 Bandwidth (Average)

\begin{tabular}{|l|c|c|c|c|}
\hline \multirow{2}{*}{ Welfare Indicators } & \multicolumn{2}{|c|}{ Baseline 2011 } & \multicolumn{2}{c|}{ Round 2016 } \\
\cline { 2 - 4 } & $\begin{array}{c}11.17 \text { to } \\
16.17\end{array}$ & 16.18 to 21.17 & $\begin{array}{c}11.17 \text { to } \\
16.17\end{array}$ & $\begin{array}{c}16.18 \text { to } \\
21.17\end{array}$ \\
\hline \multicolumn{2}{|c|}{ Women Autonomy/Mobility } & & \\
\hline Visit to market & 30.1 & 36.2 & 40.9 & 39.4 \\
\hline Visit to Health center & 32.7 & 38.8 & 40.0 & 38.7 \\
\hline Visit to Friend's house & 42.9 & 49.4 & 56.6 & 54.5 \\
\hline Visit to Religious center & 28.5 & 33.3 & 29.0 & 27.4 \\
\hline \multicolumn{2}{|c|}{ Socio-Economic \& Political Empowerment } & & \\
\hline $\begin{array}{l}\text { Decision of spending of her own earned } \\
\text { income }\end{array}$ & 86.8 & 90.2 & 95.0 & 94.7 \\
\hline Have another Child & 35.9 & 35.3 & 40.7 & 41.2 \\
\hline Children's education decision & 39.4 & 39.3 & 58.3 & 54.2 \\
\hline Minor households purchases decision & 34.7 & 34.2 & 37.8 & 37.2 \\
\hline Small investment decision & 38.3 & 37.7 & 39.1 & 35.7 \\
\hline Participation in groups outside the home & 33.0 & 32.6 & 29.6 & 28.6 \\
\hline Vote in election & 33.8 & 33.7 & 44.5 & 40.3 \\
\hline
\end{tabular}

Source: Estimated from the BISP Impact Evaluation Survey 2011 - 2016 by authors. Note: The averages of baseline and 2016 round are based on cross-sectional sample households lies within $+/-5$ bandwidth.

The outcome indicators pertinent to socio-economic and political empowerment depict increasing trend as compared to non-beneficiary women in during 2011-2016 except participation in groups outside which show decreasing trend across time.

\subsection{RDD Impact Estimates on Women Empowerment}

The results of the study discussed RDD estimate pertinent to women empowerment for 2016 crosssectional households. Table 5 indicate RDD estimate on gender norms with women perspective show that all indicators of gender norms except the category "Disagreed that family decision by men" are statistically insignificant. The variable "Disagreed that family decision by men" is statistically significant at $+/-3$ bandwidth at 4 percent level whereas it is also statistically significant at optimal bandwidth at 3 percent level. There is no other impact of RDD on other individual indicators pertinent to women perspective during 2016 but the coefficient depicted positive values. The sum of all gender norms indicators with women perspective also indicate insignificant impact of the pogramme on gender norms.

Table 5: RDD Impact Estimates on Gender Norms at various Bandwidth: Female Response

\begin{tabular}{|c|c|c|c|c|c|c|c|}
\hline \multicolumn{8}{|c|}{ RDD Estimates for 2016 Sample } \\
\hline 2016 Sample & $\begin{array}{l}\text { Disagree } \\
\text { that } \\
\text { family } \\
\text { decision } \\
\text { by men }\end{array}$ & $\begin{array}{l}\text { Agreed } \\
\text { male } \\
\text { should } \\
\text { help }\end{array}$ & $\begin{array}{l}\text { Agree that } \\
\text { women } \\
\text { should } \\
\text { work }\end{array}$ & $\begin{array}{l}\text { Agree that } \\
\text { female } \\
\text { have right } \\
\text { to express } \\
\text { opinion }\end{array}$ & $\begin{array}{l}\text { Disagree } \\
\text { that wife } \\
\text { should } \\
\text { tolerate } \\
\text { being } \\
\text { beaten }\end{array}$ & $\begin{array}{l}\text { Disagree } \\
\text { that better } \\
\text { to send son }\end{array}$ & $\begin{array}{l}\text { Sum of } \\
\text { the } \\
\text { gender } \\
\text { norms } \\
\text { measures }\end{array}$ \\
\hline \multicolumn{8}{|c|}{ +/-5 PMT Score Bandwidth } \\
\hline RD Estimates & 0.02 & 0.01 & 0.01 & -0.004 & 0.003 & -0.01 & 0.003 \\
\hline Standard Error & $(0.02)$ & $(0.02)$ & $(0.02)$ & $(0.01)$ & $(0.01)$ & $(0.02)$ & $(0.01)$ \\
\hline P-value & 0.32 & 0.55 & 0.54 & 0.83 & 0.82 & 0.59 & 0.88 \\
\hline $\begin{array}{l}\text { Sample size left of } \\
\text { the cut-off }\end{array}$ & 3536 & 2946 & 2932 & 2899 & 3536 & 3536 & 3536 \\
\hline $\begin{array}{l}\text { Sample size right of } \\
\text { the cut-off }\end{array}$ & 4008 & 3293 & 3271 & 3269 & 4008 & 4008 & 4008 \\
\hline \multicolumn{8}{|c|}{ +/-3 PMT Score Bandwidth } \\
\hline RD Estimates & 0.05 & 0.01 & 0.03 & -0.008 & 0.009 & -0.02 & 0.001 \\
\hline Standard Error & $(0.02)$ & $(0.03)$ & $(0.02)$ & $(0.02)$ & $(0.01)$ & $(0.02)$ & $(0.01)$ \\
\hline P-value & $0.04 * *$ & 0.67 & 0.29 & 0.71 & 0.59 & 0.55 & 0.96 \\
\hline Sample size left of & 2406 & 2011 & 2001 & 1971 & 2406 & 2406 & 2406 \\
\hline
\end{tabular}




\begin{tabular}{|c|c|c|c|c|c|c|c|}
\hline the cut-off & & & & & & & \\
\hline $\begin{array}{l}\text { Sample size right of } \\
\text { the cut-off }\end{array}$ & 2382 & 1969 & 1953 & 1950 & 2382 & 2382 & 2382 \\
\hline \multicolumn{8}{|l|}{ Optimal Bandwidth } \\
\hline RD Estimates & 0.06 & 0.04 & 0.03 & 0.009 & 0.01 & -0.03 & -0.001 \\
\hline Standard Error & 0.02 & $(0.04)$ & $(0.03)$ & $(0.02)$ & $(0.02)$ & $(0.03)$ & $(0.02)$ \\
\hline P-value & $0.03 * *$ & 0.35 & 0.40 & 0.73 & 0.54 & 0.40 & 0.96 \\
\hline $\begin{array}{l}\text { Sample size left of } \\
\text { the cut-off }\end{array}$ & 2194 & 2154 & 2624 & 2906 & 3561 & 3208 & 2510 \\
\hline $\begin{array}{l}\text { Sample size right of } \\
\text { the cut-off }\end{array}$ & 1378 & 762 & 1115 & 764 & 1133 & 1105 & 1246 \\
\hline
\end{tabular}

The analysis of gender norms with men's perspective as shown in Table 6 show no impact of the programme on gender norms with men's perspective. The individual coefficients of gender norms all are negative. Conceivably, the cash assistance programme could not be helpful to change men's attitude towards women in the long run. The sum of the gender norms with men's perspective is also shown insignificant impact in 2016. The prevailing social and custom norms and low women status in Pakistan does not allow women to stand along with men.

Table 6: RDD Impact Estimates on Gender Norms at various Bandwidth: Male Response

\begin{tabular}{|c|c|c|c|c|c|c|c|}
\hline \multicolumn{8}{|c|}{ RDD Estimates for 2016 Sample } \\
\hline 2016 Sample & $\begin{array}{l}\text { Disagree } \\
\text { that } \\
\text { family } \\
\text { decision } \\
\text { by men }\end{array}$ & $\begin{array}{l}\text { Agreed } \\
\text { male } \\
\text { should } \\
\text { help }\end{array}$ & $\begin{array}{l}\text { Agree that } \\
\text { women } \\
\text { should } \\
\text { work }\end{array}$ & $\begin{array}{l}\text { Agree that } \\
\text { female } \\
\text { have right } \\
\text { to express } \\
\text { opinion }\end{array}$ & $\begin{array}{l}\text { Disagree } \\
\text { that wife } \\
\text { should } \\
\text { tolerate } \\
\text { being } \\
\text { beaten }\end{array}$ & $\begin{array}{l}\text { Disagree } \\
\text { that } \\
\text { better to } \\
\text { send son }\end{array}$ & $\begin{array}{l}\text { Sum of } \\
\text { the } \\
\text { gender } \\
\text { norms } \\
\text { measures }\end{array}$ \\
\hline \multicolumn{8}{|c|}{ +/-5 PMT Score Bandwidth } \\
\hline RD Estimates & -0.04 & 0.005 & -0.008 & 0.01 & -0.03 & -0.07 & 0.02 \\
\hline Standard Error & $(0.02)$ & $(0.02)$ & $(0.03)$ & $(0.02)$ & $(0.02)$ & $(0.02)$ & $(0.02)$ \\
\hline P-value & 0.16 & 0.84 & 0.80 & 0.52 & 0.23 & $0.01 *$ & 0.48 \\
\hline $\begin{array}{l}\text { Sample size left of the } \\
\text { cut-off }\end{array}$ & 2528 & 2510 & 2505 & 2512 & 2466 & 2488 & 3536 \\
\hline $\begin{array}{l}\text { Sample size right of the } \\
\text { cut-off }\end{array}$ & 2772 & 2741 & 2722 & 2737 & 2694 & 2729 & 4008 \\
\hline \multicolumn{8}{|c|}{ +/-3 PMT Score Bandwidth } \\
\hline RD Estimates & -0.05 & -0.006 & -0.02 & 0.02 & -0.03 & -0.08 & 0.01 \\
\hline Standard Error & $(0.03)$ & $(0.03)$ & $(0.03)$ & $(0.02)$ & $(0.02)$ & $(0.03)$ & $(0.02)$ \\
\hline P-value & 0.22 & 0.86 & 0.59 & 0.43 & 0.25 & $0.02 *$ & 0.65 \\
\hline $\begin{array}{l}\text { Sample size left of the } \\
\text { cut-off }\end{array}$ & 1727 & 1718 & 1713 & 1713 & 1689 & 1701 & 2406 \\
\hline $\begin{array}{l}\text { Sample size right of the } \\
\text { cut-off }\end{array}$ & 1644 & 1627 & 1608 & 1625 & 1599 & 1616 & 2382 \\
\hline \multicolumn{8}{|l|}{ Optimal Bandwidth } \\
\hline RD Estimates & -0.04 & -0.01 & -0.04 & 0.02 & -0.06 & -0.08 & 0.03 \\
\hline Standard Error & $(0.03)$ & $(0.03)$ & $(0.04)$ & $(0.02)$ & $(0.04)$ & $(0.04)$ & $(0.03)$ \\
\hline P-value & 0.27 & 0.68 & 0.38 & 0.41 & 0.16 & $0.03 * *$ & 0.33 \\
\hline $\begin{array}{l}\text { Sample size left of the } \\
\text { cut-off }\end{array}$ & 1686 & 1737 & 1901 & 1459 & 1892 & 1860 & 2362 \\
\hline $\begin{array}{l}\text { Sample size right of the } \\
\text { cut-off }\end{array}$ & 1138 & 942 & 798 & 1114 & 617 & 1015 & 1603 \\
\hline \multicolumn{8}{|c|}{$\begin{array}{l}* \text { shows significance at } 1 \text { percent, ** shows significance at } 5 \%, * * * \text { shows significance at } 10 \% \text {. Fuzzy RD } \\
\text { estimates are used and the p-value is associated with the robust local polynomial that is bias-corrected, whilst the } \\
\text { estimates are based on the kernel triangular method. Note: The BISP poverty score was normalized so that } \\
\text { eligibility threshold }=0 \text {, Source: Estimated from the BISP Impact Evaluation Survey, } 2016 \text { round }\end{array}$} \\
\hline
\end{tabular}


The RDD results for 2016 round regarding all four mobility indicators show positive and significant on beneficiary households than non-beneficiary households. The estimates pertinent to women mobility to visit markets coefficients are positive in fixed and optimal bandwidth. The women mobility to market increased by 7 percent at $+/-5$ and $+/-3$ bandwidth and by 10 percent at optimal bandwidth depicted in Table 7. The women mobility to health center increased by 5 percent at $+/-5$ followed by 6 percent at $+/-3$ bandwidth and by 15 percent at optimal bandwidth. By looking into estimates of optimal bandwidth, the coefficients of all four measures of women mobility show positive and significant impact of the programme. At optimal bandwidth. Women mobility to friend's home and religious center is positive and statistical significant at optimal bandwidth. Women mobility to friend's home improved by 13 percent followed by women mobility to religious center by 8 percent and sum of all mobility measures by 8 percent. The visual evidence of the sum of mobility measures is depicted in Fig 1 (Appendix-I).

Table 7: RDD Impact Estimates on Women Autonomy/Mobility at various Bandwidth

\begin{tabular}{|c|c|c|c|c|c|}
\hline \multicolumn{6}{|c|}{ RDD Estimates for 2016 Sample } \\
\hline 2016 Sample & $\begin{array}{l}\text { Free mobility to } \\
\text { market }\end{array}$ & Health center & $\begin{array}{l}\text { Friend's } \\
\text { home }\end{array}$ & $\begin{array}{l}\text { Religious } \\
\text { center }\end{array}$ & $\begin{array}{c}\text { Sum of the } \\
\text { four } \\
\text { mobility } \\
\text { measures }\end{array}$ \\
\hline \multicolumn{6}{|l|}{ +/-5 PMT Score Bandwidth } \\
\hline RD Estimates & 0.07 & $0.05 * * *$ & 0.02 & 0.03 & 0.03 \\
\hline Standard Error & $(0.03)$ & $(0.02)$ & $(0.03)$ & $(0.02)$ & $(0.02)$ \\
\hline P-value & $0.01 *$ & 0.08 & 0.43 & 0.20 & 0.27 \\
\hline Sample size left of the cut-off & 3104 & 3105 & 3106 & 3068 & 3687 \\
\hline $\begin{array}{l}\text { Sample size right of the cut- } \\
\text { off }\end{array}$ & 3455 & 3457 & 3454 & 3410 & 4175 \\
\hline \multicolumn{6}{|l|}{ +/-3 PMT Score Bandwidth } \\
\hline RD Estimates & 0.07 & 0.06 & 0.02 & 0.04 & 0.03 \\
\hline Standard Error & $(0.03)$ & $(0.03)$ & $(0.03)$ & $(0.03)$ & $(0.03)$ \\
\hline P-value & $0.04 * *$ & $0.09 * * *$ & 0.55 & 0.14 & 0.41 \\
\hline Sample size left of the cut-off & 2105 & 2106 & 2107 & 2082 & 2504 \\
\hline $\begin{array}{l}\text { Sample size right of the cut- } \\
\text { off }\end{array}$ & 2064 & 2066 & 2064 & 2036 & 2490 \\
\hline \multicolumn{6}{|l|}{ Optimal Bandwidth } \\
\hline RD Estimates & 0.10 & 0.15 & 0.13 & 0.08 & 0.08 \\
\hline Standard Error & $(0.04)$ & $(0.04)$ & $(0.05)$ & 0.03 & $(0.04)$ \\
\hline P-value & $0.02 *$ & $0.001 *$ & $0.01 *$ & $0.03 * *$ & $0.08 * * *$ \\
\hline Sample size left of the cut-off & 2309 & 2523 & 2429 & 3068 & 2748 \\
\hline $\begin{array}{l}\text { Sample size right of the cut- } \\
\text { off }\end{array}$ & 820 & 587 & 561 & 774 & 848 \\
\hline
\end{tabular}

The third dimension contains RDD estimates pertaining to women socio-economic and political (SEP) empowerment which includes women decision making and voting power in election. The results are illustrated in Table 8. The RDD estimate show improvement in children's education decision by 4 percent at $+/-5$ bandwidth. The women in 2016 were able to take decisions about their child education which is good and positive sign of improvement. Women political participation indicate that women voting in election have been improved by 9 percent at $+/-5 \&+/-3$ bandwidth and by 13 percent at optimal bandwidth as compared to non-beneficiary women households. The sum of socio-economic and political empowerment show improvement by 5 percent at $+/-5$ bandwidth followed by 5 percent at $+/-3$ bandwidth 
and by 8 percent at optimal bandwidth. The visual evidence is illustrated in Fig 2, 3 \& Fig 4 (AppendixI).

Table 8: RDD Impact Estimates on Socio-Economic \& Political Empowerment (SEP) at various Bandwidth

\begin{tabular}{|c|c|c|c|c|c|c|c|c|}
\hline & & & RDD Es & imates for 2 & 16 Sample & & & \\
\hline $\begin{array}{c}2016 \\
\text { Sample }\end{array}$ & $\begin{array}{c}\text { Spending } \\
\text { decision } \\
\text { of her } \\
\text { own } \\
\text { earned } \\
\text { income }\end{array}$ & $\begin{array}{c}\text { Have } \\
\text { another } \\
\text { Child }\end{array}$ & $\begin{array}{l}\text { Children's } \\
\text { education } \\
\text { decision }\end{array}$ & $\begin{array}{c}\text { Minor } \\
\text { households } \\
\text { purchases } \\
\text { decision }\end{array}$ & $\begin{array}{c}\text { Small } \\
\text { investment } \\
\text { decision }\end{array}$ & $\begin{array}{l}\text { Participation } \\
\text { in groups } \\
\text { outside the } \\
\text { home }\end{array}$ & $\begin{array}{l}\text { Vote in } \\
\text { election }\end{array}$ & $\begin{array}{l}\text { Sum of } \\
\text { the SEP } \\
\text { indicators } \\
\text { measures }\end{array}$ \\
\hline +/-5 PMT & ore Band & dth & & & & & & \\
\hline $\begin{array}{l}\text { RD } \\
\text { Estimates }\end{array}$ & -0.006 & 0.01 & 0.04 & -0.006 & -0.002 & -0.002 & 0.09 & 0.06 \\
\hline $\begin{array}{l}\text { Standard } \\
\text { Error }\end{array}$ & $(0.02)$ & $(0.02)$ & $(0.02)$ & $(0.02)$ & $(0.02)$ & $(0.02)$ & $(0.02)$ & $(0.02)$ \\
\hline P-value & 0.76 & 0.66 & $0.08 * * *$ & 0.78 & 0.91 & 0.94 & $0.00 *$ & $0.003 *$ \\
\hline $\begin{array}{l}\text { Sample } \\
\text { size left of } \\
\text { the cut-off }\end{array}$ & 847 & 3536 & 3536 & 3536 & 3536 & 3536 & 3636 & 3536 \\
\hline $\begin{array}{l}\text { Sample } \\
\text { size right } \\
\text { of the cut- } \\
\text { off }\end{array}$ & 833 & 4008 & 4008 & 4008 & 4008 & 4008 & 4083 & 4008 \\
\hline +/-3 PMT & ore Band & dth & & & & & & \\
\hline $\begin{array}{l}\text { RD } \\
\text { Estimates }\end{array}$ & -0.03 & -0.006 & 0.04 & -0.01 & -0.03 & -0.003 & 0.09 & 0.05 \\
\hline $\begin{array}{l}\text { Standard } \\
\text { Error }\end{array}$ & $(0.02)$ & $(0.03)$ & $(0.03)$ & $(0.03)$ & $(0.03)$ & $(0.03)$ & $(0.02)$ & $(0.02)$ \\
\hline P-value & 0.16 & 0.84 & 0.17 & 0.65 & 0.41 & 0.90 & $0.00^{*}$ & $0.05 * *$ \\
\hline $\begin{array}{l}\text { Sample } \\
\text { size left of } \\
\text { the cut-off }\end{array}$ & 569 & 2406 & 2406 & 2406 & 2406 & 2406 & 2463 & 2406 \\
\hline $\begin{array}{l}\text { Sample } \\
\text { size right } \\
\text { of the cut- } \\
\text { off }\end{array}$ & 500 & 2382 & 2382 & 2382 & 2382 & 2382 & 2435 & 2382 \\
\hline Optimal B & width & & & & & & & \\
\hline $\begin{array}{l}\text { RD } \\
\text { Estimates }\end{array}$ & -0.05 & -0.01 & 0.05 & 0.004 & -0.03 & -0.0003 & 0.13 & 0.05 \\
\hline $\begin{array}{l}\text { Standard } \\
\text { Error }\end{array}$ & $(0.02)$ & $(0.03)$ & $(0.04)$ & $(0.04)$ & $(0.03)$ & $(0.04)$ & $(0.03)$ & $(0.03)$ \\
\hline P-value & 0.008 & 0.76 & 0.17 & 0.91 & 0.41 & 0.99 & $0.01 *$ & $0.08 * *$ \\
\hline $\begin{array}{l}\text { Sample } \\
\text { size left of } \\
\text { the cut-off }\end{array}$ & 768 & 2507 & 3263 & 1865 & 2356 & 2508 & 3291 & 1839 \\
\hline $\begin{array}{l}\text { Sample } \\
\text { size right } \\
\text { of the cut- } \\
\text { off }\end{array}$ & 155 & 1634 & 1102 & 1095 & 1602 & 1054 & 835 & 1454 \\
\hline
\end{tabular}

* shows significance at 1 percent, $* *$ shows significance at 5\%, *** shows significance at $10 \%$. Fuzzy RD estimates are used and the p-value is associated with the robust local polynomial that is bias-corrected, whilst the estimates are based on the kernel triangular method. Note: The BISP poverty score was normalized so that eligibility threshold = 0, Source: Estimated from the BISP Impact Evaluation Survey, 2016 round

\section{Difference in Difference Model Results}

The welfare impact of BISP cash assistance programme has computed by using DiD model approach on BISP panel households from 2011 to 2016 rounds. The results of DiD model on various indicators of women empowerment is reported in Table $9 \& 10$. The $\mathrm{DiD}$ estimate on gender norms with women perspective indicate that majority of the coefficients are positive but insignificant except the category 
'Disagree that family decision by men' which show that 6 percent of the women beneficiary disagreed with the statement of family decision by men. The DiD estimate pertinent to gender norms with men perspectives how no improvement in men's attitude towards women over time.

Table 9: DiD Impact on Welfare Indicators

\begin{tabular}{|c|c|c|c|c|c|}
\hline \multirow[b]{2}{*}{ Welfare Indicators } & \multicolumn{2}{|c|}{ Control } & \multicolumn{2}{|c|}{ Treatment } & \multirow[b]{2}{*}{$\begin{array}{c}\text { Difference-in- } \\
\text { difference Coef } \\
\text { (SE) }\end{array}$} \\
\hline & $\begin{array}{l}\text { Baseline Mean } \\
\text { (SE) }\end{array}$ & $\begin{array}{l}\text { Difference } \\
\text { Coef } \\
\text { (SE) }\end{array}$ & $\begin{array}{l}\text { Baseline Mean } \\
\text { (SE) }\end{array}$ & $\begin{array}{l}\text { Difference } \\
\text { Coef } \\
\text { (SE) }\end{array}$ & \\
\hline \multicolumn{6}{|c|}{ Gender Norms (Female Response) } \\
\hline $\begin{array}{l}\text { Disagree that family } \\
\text { decision by men }\end{array}$ & $\begin{array}{c}0.20 \\
(0.01)\end{array}$ & $\begin{array}{l}-0.01 \\
(0.02)\end{array}$ & $\begin{array}{c}0.12 \\
(0.01)\end{array}$ & $\begin{array}{l}0.05^{* * * *} \\
(0.01)\end{array}$ & $\begin{array}{l}0.06 * * * \\
(0.02)\end{array}$ \\
\hline $\begin{array}{l}\text { Agreed male should help } \\
\text { in households chores }\end{array}$ & $\begin{array}{c}0.75 \\
(0.01)\end{array}$ & $\begin{array}{l}-0.02 \\
(0.02)\end{array}$ & $\begin{array}{c}0.72 \\
(0.01)\end{array}$ & $\begin{array}{l}-0.01 \\
(0.01)\end{array}$ & $\begin{array}{c}0.00 \\
(0.03)\end{array}$ \\
\hline $\begin{array}{l}\text { Agree that women should } \\
\text { work }\end{array}$ & $\begin{array}{c}0.77 \\
(0.01)\end{array}$ & $\begin{array}{c}0.01 \\
(0.02)\end{array}$ & $\begin{array}{c}0.73 \\
(0.01)\end{array}$ & $\begin{array}{l}0.03 * * \\
(0.01)\end{array}$ & $\begin{array}{c}0.02 \\
(0.03)\end{array}$ \\
\hline $\begin{array}{l}\text { Agree that female have } \\
\text { right to express opinion }\end{array}$ & $\begin{array}{c}0.83 \\
(0.01)\end{array}$ & $\begin{array}{c}0.05 * * * \\
(0.02)\end{array}$ & $\begin{array}{c}0.80 \\
(0.01)\end{array}$ & $\begin{array}{c}0.08^{* * *} \\
(0.01)\end{array}$ & $\begin{array}{c}0.02 \\
(0.02)\end{array}$ \\
\hline $\begin{array}{l}\text { Disagree that wife should } \\
\text { tolerate being beaten }\end{array}$ & $\begin{array}{c}0.18 \\
(0.01)\end{array}$ & $\begin{array}{c}-0.08 * * * \\
(0.02)\end{array}$ & $\begin{array}{c}0.19 \\
(0.01)\end{array}$ & $\begin{array}{c}-0.10 * * * \\
(0.01)\end{array}$ & $\begin{array}{l}-0.02 \\
(0.03)\end{array}$ \\
\hline $\begin{array}{l}\text { Disagree that better to send } \\
\text { son }\end{array}$ & $\begin{array}{c}0.81 \\
(0.01)\end{array}$ & $\begin{array}{c}-0.14 * * * \\
(0.02)\end{array}$ & $\begin{array}{c}0.76 \\
(0.01)\end{array}$ & $\begin{array}{c}-0.10 * * * \\
(0.01)\end{array}$ & $\begin{array}{c}0.03 \\
(0.03)\end{array}$ \\
\hline \multicolumn{6}{|c|}{ Gender Norms (Male Response) } \\
\hline $\begin{array}{l}\text { Disagree that family } \\
\text { decision by men }\end{array}$ & $\begin{array}{c}0.19 \\
(0.02)\end{array}$ & $\begin{array}{l}0.07 * * \\
(0.02)\end{array}$ & $\begin{array}{c}0.17 \\
(0.01)\end{array}$ & $\begin{array}{l}0.06 * * \\
(0.01)\end{array}$ & $\begin{array}{c}0.00 \\
(0.03)\end{array}$ \\
\hline $\begin{array}{l}\text { Agreed male should help } \\
\text { in households chores }\end{array}$ & $\begin{array}{c}0.73 \\
(0.02) \\
\end{array}$ & $\begin{array}{c}0.02 \\
(0.02) \\
\end{array}$ & $\begin{array}{c}0.72 \\
(0.01)\end{array}$ & $\begin{array}{l}0.04 * * \\
(0.02)\end{array}$ & $\begin{array}{c}0.02 \\
(0.03)\end{array}$ \\
\hline $\begin{array}{l}\text { Agree that women should } \\
\text { work }\end{array}$ & $\begin{array}{c}0.52 \\
(0.02)\end{array}$ & $\begin{array}{l}-0.01 \\
(0.03)\end{array}$ & $\begin{array}{c}0.49 \\
(0.01)\end{array}$ & $\begin{array}{l}0.04 * * \\
(0.02)\end{array}$ & $\begin{array}{c}0.05 \\
(0.03)\end{array}$ \\
\hline $\begin{array}{l}\text { Agree that female have } \\
\text { right to express opinion }\end{array}$ & $\begin{array}{c}0.72 \\
(0.02)\end{array}$ & $\begin{array}{c}0.13 * * * \\
(0.02)\end{array}$ & $\begin{array}{c}0.69 \\
(0.01)\end{array}$ & $\begin{array}{c}0.15^{* * *} \\
(0.01)\end{array}$ & $\begin{array}{c}0.02 \\
(0.03)\end{array}$ \\
\hline $\begin{array}{l}\text { Disagree that wife should } \\
\text { tolerate being beaten }\end{array}$ & $\begin{array}{c}0.36 \\
(0.02) \\
\end{array}$ & $\begin{array}{c}-0.06^{* * * *} \\
(0.02) \\
\end{array}$ & $\begin{array}{c}0.27 \\
(0.01)\end{array}$ & $\begin{array}{c}-0.12^{* * * *} \\
(0.01)\end{array}$ & $\begin{array}{l}-0.05^{*} \\
(0.03)\end{array}$ \\
\hline $\begin{array}{l}\text { Disagree that better to send } \\
\text { son }\end{array}$ & $\begin{array}{c}0.73 \\
(0.02)\end{array}$ & $\begin{array}{l}0.06^{* *} \\
(0.02)\end{array}$ & $\begin{array}{c}0.67 \\
(0.01)\end{array}$ & $\begin{array}{c}0.05 * * * \\
(0.02)\end{array}$ & $\begin{array}{l}-0.00 \\
(0.03)\end{array}$ \\
\hline
\end{tabular}

The results about women participation in voting shows positive and significant impact by 9 percentage points. Women participation in voting show that more percentage of beneficiaries women due to having valid CNIC are now participating in election for voting than those of non-beneficiary women over time. The statistics of women participation in taking small investment decision shows positive and significant increase by 7 percentage points as compared to non-beneficiary women over time whereas, decision about children's education have improved by 5 percentage points in the same period that shows the amount of cash grant provision only to women improve her decision power to spend money on child education. The results about women mobility shows positive and highly significant impact of the programme as its shows increase women mobility to market by 4 percentage points followed by women mobility to friend's home by 10 percentage points and increase in women mobility to religious center by 7 percentage points and women mobility to health center by 6 percentage points over time as compared to non-beneficiary households. The sum of all four mobility measures indicate improvement by 11 percentage points over time.

Table 10: DiD Impact on Welfare Indicators

\begin{tabular}{|c|c|c|c|c|c|}
\hline \multirow[b]{2}{*}{ Welfare Indicators } & \multicolumn{2}{|c|}{ Control } & \multicolumn{2}{|c|}{ Treatment } & \multirow[b]{2}{*}{$\begin{array}{l}\text { Difference-in- } \\
\text { difference Coef } \\
\text { (SE) }\end{array}$} \\
\hline & $\begin{array}{l}\text { Baseline Mean } \\
\text { (SE) }\end{array}$ & $\begin{array}{l}\text { Difference } \\
\text { Coef } \\
(\mathrm{SE})\end{array}$ & $\begin{array}{l}\text { Baseline Mean } \\
\text { (SE) }\end{array}$ & $\begin{array}{l}\text { Difference } \\
\text { Coef } \\
\text { (SE) }\end{array}$ & \\
\hline
\end{tabular}




\begin{tabular}{|c|c|c|c|c|c|}
\hline \multicolumn{6}{|c|}{ Socio-economic \& Political Empowerment } \\
\hline Voting in election & $\begin{array}{c}0.64 \\
(0.02)\end{array}$ & $\begin{array}{l}0.17 * * * \\
(0.02)\end{array}$ & $\begin{array}{c}0.62 \\
(0.01)\end{array}$ & $\begin{array}{l}0.26^{* * *} \\
(0.01)\end{array}$ & $\begin{array}{c}0.09 * * * \\
(0.03)\end{array}$ \\
\hline $\begin{array}{l}\text { Decision power on her } \\
\text { own earned spending }\end{array}$ & $\begin{array}{c}0.21 \\
(0.01)\end{array}$ & $\begin{array}{l}-0.01 \\
(0.02)\end{array}$ & $\begin{array}{c}0.22 \\
(0.01) \\
\end{array}$ & $\begin{array}{c}0.00 \\
(0.01)\end{array}$ & $\begin{array}{c}0.01 \\
(0.02) \\
\end{array}$ \\
\hline $\begin{array}{l}\text { Decision of having another } \\
\text { child }\end{array}$ & $\begin{array}{c}0.36 \\
(0.02)\end{array}$ & $\begin{array}{c}0.06 * * * \\
(0.02)\end{array}$ & $\begin{array}{c}0.36 \\
(0.01)\end{array}$ & $\begin{array}{c}0.07 * * * \\
(0.01)\end{array}$ & $\begin{array}{c}0.00 \\
(0.01)\end{array}$ \\
\hline Minor purchases decision & $\begin{array}{c}0.35 \\
(0.02)\end{array}$ & $\begin{array}{c}0.02 \\
(0.02)\end{array}$ & $\begin{array}{c}0.38 \\
(0.01)\end{array}$ & $\begin{array}{c}0.04 \\
(0.01)\end{array}$ & $\begin{array}{c}0.01 \\
(0.03)\end{array}$ \\
\hline Small investment decision & $\begin{array}{c}0.39 \\
(0.02)\end{array}$ & $\begin{array}{l}-0.04 \\
(0.02)\end{array}$ & $\begin{array}{c}0.40 \\
(0.01)\end{array}$ & $\begin{array}{l}0.03 * * \\
(0.01)\end{array}$ & $\begin{array}{l}0.07 * * \\
(0.03)\end{array}$ \\
\hline Child education decision & $\begin{array}{c}0.14 \\
(0.02) \\
\end{array}$ & $\begin{array}{c}0.16 * * * \\
(0.02) \\
\end{array}$ & $\begin{array}{c}0.41 \\
(0.01) \\
\end{array}$ & $\begin{array}{c}0.21 * * * \\
(0.01)\end{array}$ & $\begin{array}{l}0.05^{*} \\
(0.03) \\
\end{array}$ \\
\hline $\begin{array}{l}\text { Participation in group } \\
\text { outside }\end{array}$ & $\begin{array}{c}0.33 \\
(0.02)\end{array}$ & $\begin{array}{l}-0.04 * \\
(0.02)\end{array}$ & $\begin{array}{c}0.34 \\
(0.01)\end{array}$ & $\begin{array}{l}-0.00 \\
(0.01)\end{array}$ & $\begin{array}{c}0.04 \\
(0.03)\end{array}$ \\
\hline \multicolumn{6}{|c|}{ Women Autonomy/Mobility } \\
\hline Free mobility to market & $\begin{array}{c}0.36 \\
(0.02)\end{array}$ & $\begin{array}{l}0.05^{* *} \\
(0.02)\end{array}$ & $\begin{array}{c}0.27 \\
(0.01)\end{array}$ & $\begin{array}{c}0.09 * * * \\
(0.01)\end{array}$ & $\begin{array}{l}0.04^{*} \\
(0.03)\end{array}$ \\
\hline $\begin{array}{l}\text { Free mobility to friend's } \\
\text { home }\end{array}$ & $\begin{array}{c}0.50 \\
(0.02)\end{array}$ & $\begin{array}{l}0.07 * * \\
(0.02)\end{array}$ & $\begin{array}{c}0.40 \\
(0.01)\end{array}$ & $\begin{array}{c}0.17 * * * \\
(0.01)\end{array}$ & $\begin{array}{c}0.10^{* * *} \\
(0.03)\end{array}$ \\
\hline $\begin{array}{l}\text { Free mobility to religious } \\
\text { center }\end{array}$ & $\begin{array}{c}0.33 \\
(0.02)\end{array}$ & $\begin{array}{c}-0.06 * * * \\
(0.02)\end{array}$ & $\begin{array}{c}0.25 \\
(0.01)\end{array}$ & $\begin{array}{c}0.01 \\
(0.01)\end{array}$ & $\begin{array}{c}0.07 * * * \\
(0.03)\end{array}$ \\
\hline $\begin{array}{l}\text { Free mobility to health } \\
\text { center }\end{array}$ & $\begin{array}{c}0.39 \\
(0.02)\end{array}$ & $\begin{array}{c}0.00 \\
(0.02)\end{array}$ & $\begin{array}{c}0.30 \\
(0.01)\end{array}$ & $\begin{array}{c}0.07 * * * \\
(0.01)\end{array}$ & $\begin{array}{l}0.06^{* * *} \\
(0.03)\end{array}$ \\
\hline Sum of mobility measures & $\begin{array}{c}0.48 \\
(0.02)\end{array}$ & $\begin{array}{c}0.02 \\
(0.02)\end{array}$ & $\begin{array}{c}0.38 \\
(0.01)\end{array}$ & $\begin{array}{c}0.14^{* * *} \\
(0.01)\end{array}$ & $\begin{array}{c}0.11^{* * * *} \\
(0.03)\end{array}$ \\
\hline
\end{tabular}

\section{Conclusion and Policy Implications}

The study evaluated the impact of BISP unconditional cash transfer programme on BISP beneficiary household women by using Fuzzy RDD model approach on cross-sectional households, 2016 and DiD model on panel housheolds 20112016. The women empowerment have been quantified through dimensions centered on gender norms, women autonomy/mobility and socio-economic and political empowerment of women. The results of RDD estimate observed that BISP had positive and significant impact on women socio-economic and political empowerment and women mobility in 2016 whilst the study has observed no significant impact in improving gender norms with men's perspective. The DiD model indicate positive and significant improvement in socio-economic and political empowerment and women mobility over time whilst the DiD model has not observed any significant improvement in gender norms with men's perspective overtime. This shows that in developing countries like Pakistan, women are not as much stronger with men's perspective due to prevailing customs and norms. The men belonging to extreme poor class are used to beating, humiliating and insulting women due to less education and conservative attitude that may take time to change. In the prevailing situation in Pakistan, women status in perceived very low as compared to other countries whereas women empowerment is linked with economic growth of the country (Duflo, 2011). The increase in women empowerment measures ultimately leads to improve economy of Pakistan in future. Empowering women through various safety net initiatives may lead to reduce intergenerational transmission of poverty as the women who received cash assistance are more willing to spend on her child education and health. The provision of cash assistance to women may likely to improve child nutrition in return and reduce child labor as well that exert impact on reducing poverty in future. Increase in amount of cash transfer suggestive subject to conditions will also improve the socio-economic stability of the beneficiary household's women in long run. 


\section{References}

Adato, M., D. Mindek. \& Quisumbing, A. (2000). The Impact of PROGRESA on Women's Status and Intra-household Relations. Washington: International Food Policy Research Institute.

Ambler, K. (2016). Bargaining with Grandma: The Impact of the South African Pension on Household Decision Making. Journal of Human Resources.

Ambler, K., \& De Brauw. (2017). The Impacts of Cash Transfers on Women's Empowerment: Learning from Pakistan's BISP Program.

Attanasio, O., \& Lechene, V. (2002). Testing of Income Pooling in Household Decisions. Review of Economic Dynamics 5(4): 720-748.

Baird, S., Ferreira, Chirwa, E., De Hooper, J., \& Ozler, B. (2013). Girl Power: Cash Transfer and Adolescent Welfare. Evidence from a Cluster- Randomized Experiment in Malawi. NBER Working Paper 19479.

Bandiera, O., N. Buehren., R. Burgess., M. Goldstein., S. Gulesci., I. Rasul. \& M. Sulaiman (2012). "Empowering Adolescent Girls: Evidence from a Randomized Control Trial in Uganda." http://www.ucl.ac.uk/ uctpimr/research/ELA.pdf. Accessed on September 3, 2013.

Bari, F., Hooper, E., Kardar, S., Khan, S., Mohammed, I., \& Sayeed, A. (2005). Conceptualizing a Social Protection Framework for Pakistan. Islamabad: Asian Development Bank. (Pakistan Poverty Assessment Update, Background Paper Series, Background Paper 4).

Barrientos, A., \& Hulme, D. (2008). Social Protection for the Poor and the Poorest: Concepts, Policies and Politics. New York: Palgrave Macmillon.

De Brauw.A., Gilligan, Daniel.O. Hoddinott, J., \& Shalini, R. (2014). The Impact of Bolsa Família on Women's Decision Making Power. World Development 59: 487-504.

Duflo, Esther. 2011. "Women's Empowerment and Economic Development," Journal of Economic Literature 50(4): 1051-1079

(2003). Grandmothers and Granddaughters: Old-Age Pensions and Intrahousehold Allocation in South Africa.'World Bank Economic Review, 17 (1), 1-25.

FAO (Food and Agriculture Organization). (2015). The State of Food and Agriculture: Social Protection and Agriculture: Breaking the Cycle of Rural Poverty. Rome: Food and Agriculture Organization.

GoP, (2018). Government of Pakistan. Pakistan Economic Survey 2018-19. Finance Division Islamabad.

Handa S., Peterman, D., Seidenfed, D. \& Tembo, G. (2015) Income transfer and maternal health: Evidence from a national randomized social cash transfer program in Zambia.

Handa, S., Amber, P., Ben, D., \& Marco, S., (2009). Opening up Pandora's Box: The Effect of Gender Targeting and Conditionality on Household Spending Behavior in Mexico's Progresa Program. World Development 37(6): 1129-114.

Hoddinott, J., \& Haddad, L. (1995). Does female income share influence household expenditure? Evidence from Cote d'Ivoire. Oxford Bulletin of Economics and Statistics, 57(1), 77-96.

Holmes, R., \& Jones, N. (2013). Gender and Social Protection in the Developing World: Beyond Mothers and Safety Nets. Zed Books.

Jamal, H. (2010). A Profile of Social Protection in Pakistan: An Appraisal of Empirical Literature. Social Policy and Development Centre (SPDC). Journal of Development Research, 17(1), 823.http://dx.doi.org/10.1080/09578810500066456

Jeejebhoy, Shireen, and Zeba A. Sathar. 2001. "Women's Autonomy in India and Pakistan: The Influence of Religion and Region," Population and Development Review 27(4): 687-712.

Kabeer, N. (2001). Reflections on the Measurement of Women's Empowerment. In A. Sisask (Series Ed.), Sida studies no. 3: Discussing Women's Empowerment: Theory and practice (pp. 17-57). Novum Grafiska AB: Stockholm, Sweden.

Kandpal, E., K. Baylis, \& M. Arends-Kuenning. (2013). Measuring the Effect of a Community-level Program on Women's Empowerment Outcomes: Evidence from India. The World Bank, Policy Research Working Paper No. 6399. 
Lundberg, S., R. A. Pollak, \& T. J. Wales (1997). Husbands and Wives Pool Their Resources? Evidence from the United Kingdom Child Benefit. Journal of Human Resources 32 (3), 463-80.

McCrary, Justin. 2008. "Manipulation of the Running Variable in the Regression Discontinuity Design: A Density Test," Journal of Econometrics 142(2): 698-714.

Natali, S., Handa S., Peterman, D., Seidenfed, D. \& Tembo, G. (2016) Making Money Work: Unconditional cash transfer allow women to save and re-invest in rural Zambia. UNICEF. Office of Research- Innocenti Working Paper: WP-2016-02 UNICEF.

Nayyab, D., \& Farooq, S. (2014). Effectiveness of Cash Transfer Programmes for Household Welfare in Pakistan: The Case of the Benazir Income Support Programme. Pakistan Institute of Development Economics (PIDE). Poverty and Social Dynamics Paper Series PSDPS.

OPM, (2016). Oxford Policy Management. Final Impact Evaluation of Unconditional Cash Transfer of BISP. Bisp.gov.pk

OPM, (2019). Data Submission Report for Final Impact Evaluation of Unconditional Cash Transfer of BISP. Bisp.gov.pk

Pitt, M. M., S. R. Khandker, \& J. Cartwright. (2006). Empowering Women with Micro Finance: Evidence from Bangladesh. Economic Development and Cultural Change, 54 (4) 791-831.

Rangel, M. A. (2006). Alimony Rights and Intrahousehold Allocation of Resources: Evidence from Brazil. Economic Journal, 116 (513), 627-658.

Sabates, Wheeler, R., \& Devereux, S. (2007). Social Protection for Transformation. IDS Bulletin 38 N. 3. Brighton, UK, IDS.

Schultz, T. Paul. (2004). School Subsidies for the Poor: Evaluating the Mexican PROGRESA Poverty Program, Journal of Development Economics 74(1): 199-250.

Shehzad, I. (2011) Benazir Income Support Programme and its Impact on Women's Empowerment

Shepherd A., R. Marcus., \& A. Barrientos. (2004). Policy Paper on Social Protection. Department of International Development (DFID), UK

Siddiki, O.F., Homes, R., Jahan, F., \& Chowdhury, F.S. (2014). How do Safety Nets Contribute to Social Inclusion in Bangladesh?

Thomas, D. (1990). Intrahousehold Resource Allocation: An Inferential Approach. Journal of Human Resources, 25(4), 635-664.

Thomas, D. (1997). Incomes, Expenditures and Health Outcomes: Evidence on Intra-household allocation.

United Nations. (1995). Fourth World Conference on Women Beijing Declaration.

World Bank, (2018). The State of Social safety Nets, World Bank Group, Washington DC

World Bank. (2015). The State of Social Safety Nets, World Bank Group, Washington DC

Yoong, J. Rabinovich, L. \& Diepeveen, S. 2012. The impact of economic resource transfers to women versus men: a systematic review. Technical report. London, EPPI-Centre, Social Science Research Unit, Institute of Education, University of London.

Zuneira, S. Amjad., Usman M., \& Farooq S. (2018) Targeting and Effectiveness of Social Safety Net Programmes: The Case of Zakat and BISP in Pakistan. Nust Journal of Social Sciences and Humanities. Volume 4, Number 2. 
Figure 1: Mobility Index

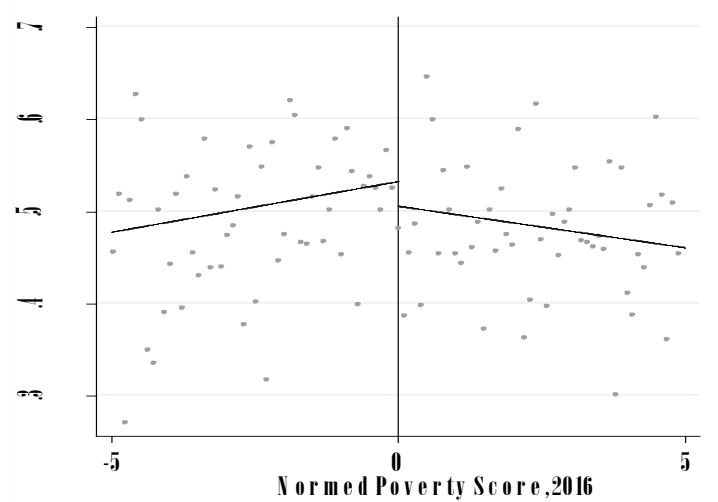

Figure 2: Voting in Election

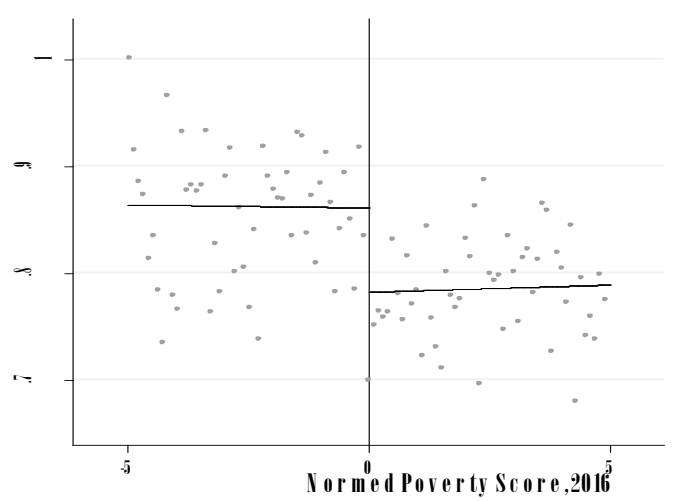

Source: Estimated from the BISP Impact Evaluation Survey 2016 by authors. Fig 1 depict discontinuity in sum mobility measures (index) and Fig 2 show discontinuity in voting in election with normed poverty score limited to +/-5.

\section{Fig 3: Child Education Decision}

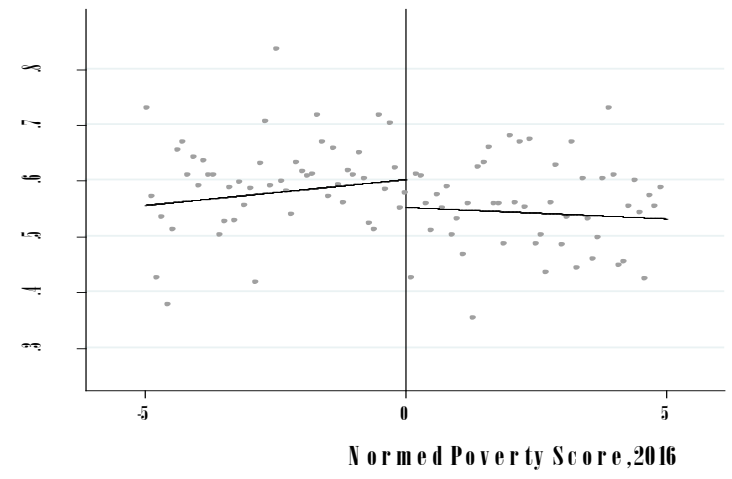

Fig 4: SEP-Empowerment Index

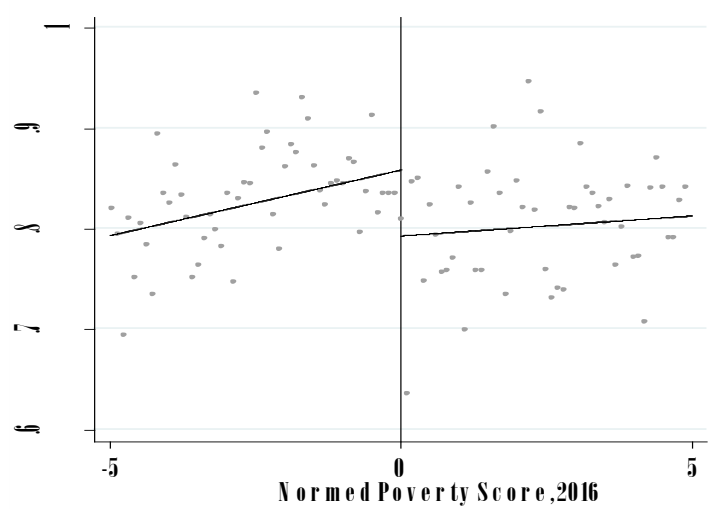

Source: Estimated from the BISP Impact Evaluation Survey 2016 by authors. Fig 3 depict discontinuity in child education decision and Fig 4 show discontinuity in sum of SEP-empowerment indicators (index) with normed poverty score limited to +/5 bandwidth.. 
Table 1: Women Empowerment Indicators and Data Source

\begin{tabular}{|c|c|}
\hline Woman Empowerment Indicators & Data Source \\
\hline $\begin{array}{l}\text { Gender Perspective } \\
\text { Disagreed that family decision should be taken by } \\
\text { men } \\
\text { Agreed if wife is working outside, husband should } \\
\text { help in chores } \\
\text { Agreed if married women allows to works outside if } \\
\text { she likes } \\
\text { Agreed to express her opinion } \\
\text { Disagreed if being beaten by her husband } \\
\text { Disagreed to send son to school than daughter }\end{array}$ & $\begin{array}{l}\text { Men's Questionnaire \& Women's Form, The variable is } \\
\text { constructed by combining agree/strongly agree or } \\
\text { disagree/strongly disagree options by using } 2011 \text { and } \\
2016 \text { round. The positive outcome is coded as ' } 1 \text { ' } \\
\text { whereas negative outcome is coded as ' } 0 \text { '. }\end{array}$ \\
\hline $\begin{array}{l}\text { Women Autonomy/Mobility } \\
\text { Freely visit to market } \\
\text { Health center } \\
\text { Friend's house } \\
\text { Religious center }\end{array}$ & $\begin{array}{l}\text { The variables constructed by using Women's form only } \\
\text { for } 2011 \text { and } 2016 \text { rounds. The variable constructed } \\
\text { based on women mobility to various places where } \\
\text { mobility alone is coded as ' } 1 \text { ' and mobility with } \\
\text { someone and no mobility is coded as ' } 0 \text { '. }\end{array}$ \\
\hline $\begin{array}{l}\text { Socio-economic and political empowerment } \\
\text { Decision of spending of her own earned income } \\
\text { Have another Child } \\
\text { Children's education decision } \\
\text { Minor households purchases decision } \\
\text { Small investment decision } \\
\text { Participation in groups outside the home } \\
\text { Vote in election }\end{array}$ & $\begin{array}{l}\text { The variables constructed by using Women's form only } \\
\text { for } 2011 \text { and } 2016 \text { rounds only. The positive outcome is } \\
\text { coded as ' } 1 \text { ' whereas the negative outcome is coded as } \\
\text { ' } 0 \text { '. }\end{array}$ \\
\hline
\end{tabular}

